\title{
THE ASH CONTENT OF THE PLOUGH LAYER OF PEAT LANDS CULTIVATED BY DIFFERENT METHODS
}

\author{
YRJö Pessi \\ Society of Peat Cultivation, Experimental Station Leteensuo
}

Received June 15, 1961

The ash content of the peat in Finnish bogs in their natural condition is rarely higher than $10 \%$. The lowest ash content is encountered in Sphagnum bogs (3). In the course of cultivation the ash content of the peat increases owing to the effects of fertilizers and soil improvement. As peat has an inherently low ash content, the increase caused by the cultivation measures has a favourable effect on the physical properties of the soil as regards the thriving of cultivated plants. Fertilizing and liming are not applied with this result in mind, but mineral soil is frequently added as a soil improving agent to peat soils with the express purpose of changing the physical properties of the peat. This measure is often repeated after a few decades on the assumption that the mineral soil has disappeared from the plough layer for one reason or another.

The purpose of the present investigation is to report on the ash content of the plough layer of cultivated peat lands today as the outcome of agricultural use during several decades and according to different cultivation techniques. The investigation material was collected in 1960 .

\section{Objects of investigation}

A number of long-term soil improvement tests at the Experimental Station of Northern Pohjanmaa at Ruukki $\left(\lambda=25.1^{\circ} \mathrm{E}, \varphi=64.6^{\circ} \mathrm{N}\right)$, the Experimental Station of the Peat Cultivation Society at Leteensuo $\left(\lambda=24.3^{\circ} \mathrm{E}, \varphi=61.6^{\circ} \mathrm{N}\right)$ and the Experimental Station of the same Society at Tohmajärvi $\left(\lambda=30.2^{\circ} \mathrm{E}, \varphi=62.1^{\circ} \mathrm{N}\right)$ were chosen as objects of the investigation. Several tests now in progress at these stations have been carried on through many decades. Attention was paid to ash content conditions in fen land as well as Sphagnum bogs. The peats concerned in the following tests were studied in this investigation. 
Let e e n s u o

Claying and sand addition test on fen land. The peat on the test area consists of forest sedge peat. The experiment was started in 1910, in which year claying and sand addition was performed for the first time. Mineral soil additions of 100 , 200,300 and $400 \mathrm{~m}^{3}$ per hectare were used. Claying and sand addition were repeated according to the same experimental plan in 1928. The results of the investigation are stated as referring to the soil improving agent additions of 200, 400, 600 and $800 \mathrm{~m}^{3}$ per hectare, respectively, and it should be noted that these quantities have been applied in two instalments. Several different fertilizations have also been included in the test. In this connection the completely unfertilized test plot and the treatments with annually recurring phosphate and potassium fertilization $(100 \mathrm{~kg}$ $\mathrm{P}_{2} \mathrm{O}_{5}$ and $100 \mathrm{~kg} \mathrm{~K} 2 \mathrm{O}$ per hectare) have been subjected to study. The experimental plants were spring cereals, hay, and root crops. The fertilizers were mostly superphosphate and potassium salt. Vesikivi (7) has given an account of this experiment and in part of its results from the first decades of its duration.

At the time when the area was brought into cultivation, the following contents of its peat were recorded: $\mathrm{N} 3.19, \mathrm{SiO}_{2} 3.66, \mathrm{SO}_{3} 0.88, \mathrm{P}_{2} \mathrm{O}_{5} 0.23, \mathrm{Al}_{2} \mathrm{O}_{3}+\mathrm{Fe}_{2} \mathrm{O}_{3}$ $2.97, \mathrm{MnO} 0.02, \mathrm{CaO} 2.01, \mathrm{MgO} 0.28, \mathrm{~K}_{2} \mathrm{O} 0.13, \mathrm{Na}_{2} \mathrm{O} 0.07 \%(6)$. The kind of mineral

Table 1. Chemical composition of the mineral soil used in the soil improving tests at Leteensuo (7).

\begin{tabular}{lcc}
\hline & $\begin{array}{c}\text { Constituents soluble in } \\
\text { Clay }\end{array}$ & $\begin{array}{c}\mathrm{HCl}, \% \\
\text { Sand }\end{array}$ \\
& & \\
$\mathrm{SiO}_{2}$ & 0.49 & 0.20 \\
$\mathrm{SO}_{3}$ & 0.07 & 0.03 \\
$\mathrm{P}_{2} \mathrm{O}_{5}$ & 0.10 & 0.06 \\
$\mathrm{Al}_{2} \mathrm{O}_{3}+\mathrm{Fe}_{2} \mathrm{O}_{3}$ & 5.14 & 1.01 \\
$\mathrm{MnO}$ & 0.01 & 0.01 \\
$\mathrm{CaO}$ & 0.47 & 0.08 \\
$\mathrm{MgO}$ & 0.47 & 0.05 \\
$\mathrm{~K}_{2} \mathrm{O}$ & 0.22 & 0.06 \\
$\mathrm{Na}_{2} \mathrm{O}$ & 0.11 & 0.05
\end{tabular}

Table 2. Mechanical composition and $\mathrm{pH}$ value of the mineral soil used in the soil improving tests at Leteensuo (7).

\begin{tabular}{|c|c|c|}
\hline Grain size, mm $\varnothing$ & Clay, \% & Sand, $\%$ \\
\hline 2 & 0.0 & 0.0 \\
\hline-0.2 & 0.0 & 21.5 \\
\hline $0.2-0.02$ & 5.0 & 76.5 \\
\hline $0.02-0.002$ & 17.5 & 2.0 \\
\hline 0.002 & 77.5 & - \\
\hline Total & 100 & 100 \\
\hline $\mathrm{pH}$ & 5.9 & 4.4 \\
\hline
\end{tabular}


soil used for soil improvement can be seen from the results of th analysis preseneted in Table 1 (7, p. 34), while Table 2 gives its mechanical composition (7, p. 34).

Claying test on fen land. The peat on the test area is forest sedge peat. Cultivation of the area was started in 1921 and the experiment proper was commenced in 1923. One half of the experimental strip was clayed (at $200 \mathrm{~m}^{3}$ per hectare) in 1923; repeated claying at the same rate was done in 1941. A potassium fertilizing test has been combined with this experiment. The potassium fertilizer quantities were initially equivalent to $0,20,40,60$ and $80 \mathrm{~kg} \mathrm{~K}_{2} \mathrm{O}$ per hectare, but since 1930 the annual quantities of $0,30,60,90$ and $120 \mathrm{~kg}$ per hectare have been applied. The notation of the treatments used in this work refers to the latter fertilizing plan. The fertilizing test plots were $50 \mathrm{~m}^{2}$ in size each. Their location has been described in detail in a previous publication (5, p. 4). As base fertilization, the entire test area received an annual phosphate fertilization equivalent to about $300 \mathrm{~kg}$ superphosphate per hectare. No nitrogen fertilizer was given. The experimental plants cultivated on this area and the test results have been presented on a previous occasion (5).

The test is immediately adjacent to the above-mentioned claying and sand addition test and the peat quality is therefore largely identical in both tests. The same clay was also used for soil improvement in both instances.

Liming and claying test on Sphagnum bog. The peat on the test area is Sphagnum peat, mainly composed of Sph. fuscum moss. The area was cleared for cultivation in 1921 and the test was started in 1923. One half of the test strip was clayed at $300 \mathrm{~m}^{3}$ per hectare. Of the lime quantities provided by the experimental plan $(0,1,2,3$ and 4 t ons $\mathrm{CaO}$ per hectare) one half was given in the spring of 1923 and the other half in the spring of 1924. The annual fertilization varied in the range equivalent to $100-300 \mathrm{~kg}$ superphosphate, $200 \mathrm{~kg} 40 \%$ potassium salt and $100-300 \mathrm{~kg}$ calcium nitrate per hectare. Stable manure was given altogether 51 tons per hectare in 1923 and 1931. The results of the experiment up to 1957 have been presented in a previous publication (4), which also gives an account of the location of the test plots. The properties of the clay used for soil improvement can be seen from Tables 1 and 2 . The ash content of uncultivated peat near the test was $1.0 \%$.

Claying, sand addition and liming test on Sphagnum bog. The peat on the test area is similar to that in the preceding test. The area was cleared for cultivation in 1930 and the mineral soil additions were spread in 1932. One half of the test strip had been limed (with $4000 \mathrm{~kg}$ slaked lime per hectare), and this was also done in the spring of 1932. The liming was repeated (at $2000 \mathrm{~kg}$ per hectare) in 1937. Stable manure was given in 1932 and 1935, altogether 70 tons per hectare. The annual administration of artificial fertilizers was equivalent to $200-250 \mathrm{~kg}$ superphosphate, $200-300 \mathrm{~kg} 40 \%$ potassium salt and $200-300 \mathrm{~kg}$ calcium nitrate per hectare. The test results up to 1957 have been reported in a previous publication (4), which also gives a detailed account of the location of the test plots. The properties of the mineral soil used for soil improvement can be seen from Tables 1 and 2 . 


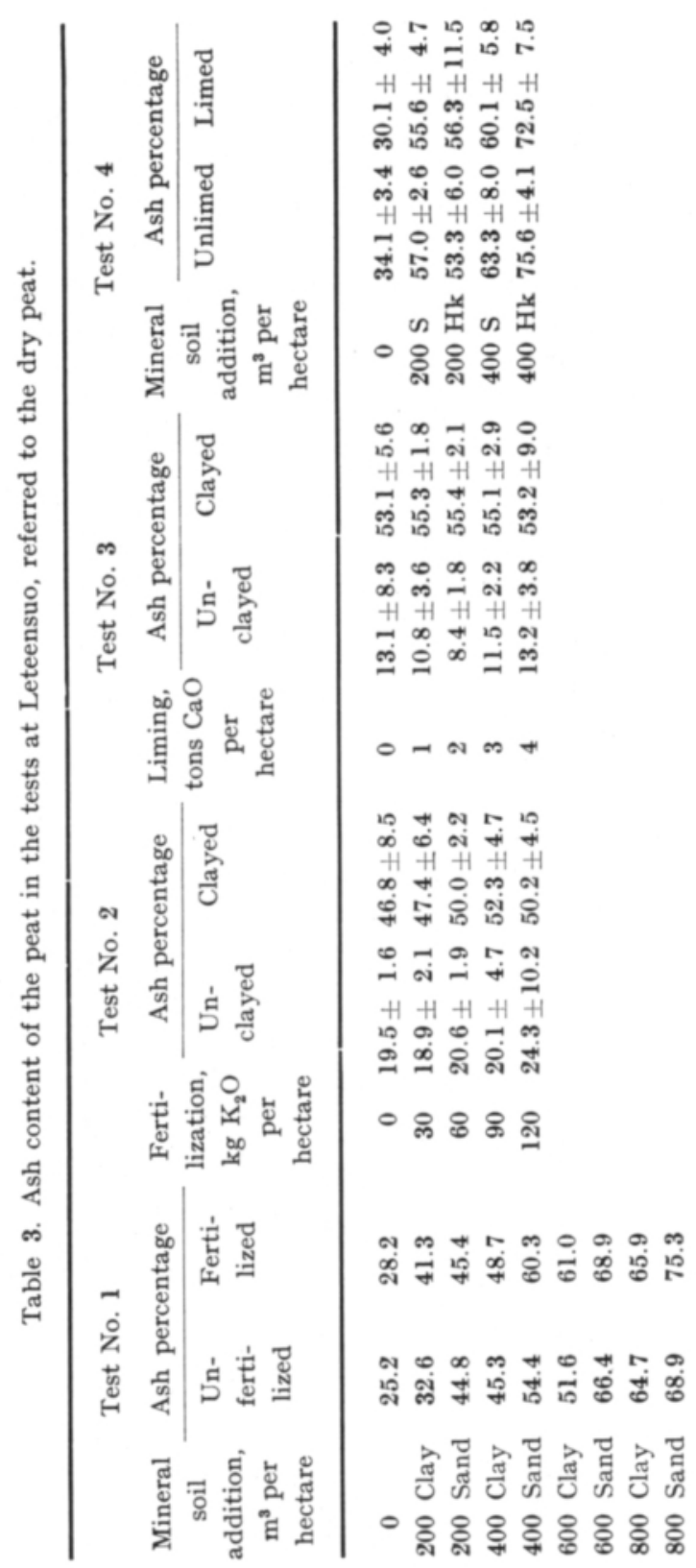


Toh m a järvi

Claying and sand addition test on fen land. The peat on the test area consists of forest sedge peat. The area was cleared for cultivation in 1932; prior to this it had served as undrained meadow land. The experiment was established in 1935, at which time the soil improving agents were applied. Various fertilizing tests were combined with the experiment. The following combinations of soil improvement and fertilization were chosen as subjects of the present investigation: Completely unfertilized plots and phosphate and potassium-fertilized $\left(50 \mathrm{~kg}_{2} \mathrm{O}_{5}\right.$ and $80 \mathrm{~kg} \mathrm{~K}_{2} \mathrm{O}$ per hectare) plots without soil improving agents and with addition of $200 \mathrm{~m}^{3}$ clay, $200 \mathrm{~m}^{3}$ fine sand, $200 \mathrm{~m}^{3}$ gravel and $200 \mathrm{~m}^{3}$ fine sand of another quality per hectare, respectively. The unfertilized and fertilized samples were lumped together.

Table 4. Ash content of the peat in the tests at Ruukki and Tohmajärvi, referred to the dry peat.

\begin{tabular}{|c|c|c|c|c|c|c|c|c|}
\hline \multirow{3}{*}{$\begin{array}{l}\text { Clay addi- } \\
\text { tion, } \mathrm{m}^{3} \\
\text { per hectare }\end{array}$} & \multirow{2}{*}{\multicolumn{2}{|c|}{$\begin{array}{l}\text { Test No. } 5 \\
\text { Ash percentage }\end{array}$}} & \multirow{3}{*}{$\begin{array}{l}\text { Soil } \\
\text { improving } \\
\text { treatment }\end{array}$} & \multirow{2}{*}{\multicolumn{2}{|c|}{$\begin{array}{l}\text { Test No. } 6 \\
\text { Ash percentage }\end{array}$}} & \multicolumn{3}{|c|}{ Test No. 7} \\
\hline & & & & & & \multirow{2}{*}{\multicolumn{2}{|c|}{$\begin{array}{l}\text { Mineral soil } \\
\text { addition, } \\
\mathrm{m}^{3} \text { per hectare }\end{array}$}} & \multirow{2}{*}{$\begin{array}{c}\text { Ash } \\
\text { percentage }\end{array}$} \\
\hline & $\begin{array}{c}\text { Unferti- } \\
\text { lized }\end{array}$ & $\begin{array}{l}\text { Ferti- } \\
\text { lized }\end{array}$ & & $\begin{array}{l}\text { Unferti- } \\
\text { lized }\end{array}$ & $\begin{array}{r}\text { Ferti- } \\
\text { lized }\end{array}$ & & & \\
\hline 0 & $17.2 \pm 2.1$ & $16.7 \pm 0.6$ & None & $20.5 \pm 6.4$ & $18.8 \pm 2.6$ & & 0 & $42.8 \pm 11.0$ \\
\hline 100 & $31.5 \pm 0.7$ & $32.6 \pm 2.3$ & Clayed & $60.7 \pm 5.0$ & $69.6 \pm 1.6$ & Fine sand & 200 & $66.1 \pm 2.2$ \\
\hline 200 & $45.2 \pm 1.8$ & $43.7 \pm 1.5$ & $\begin{array}{l}\text { Limed } \\
\text { Clayed anc }\end{array}$ & $32.5 \pm 3.8$ & $26.7 \pm 4.0$ & Clay & 200 & $66.2 \pm 2.9$ \\
\hline 300 & $43.1 \pm 16.2$ & $47.8 \pm 5.2$ & limed & $60.1 \pm 4.3$ & $57.9 \pm 9.9$ & $\begin{array}{l}\text { Fine sand } \\
\text { Gravel }\end{array}$ & $\begin{array}{r}200 \\
200 \\
0\end{array}$ & $\begin{array}{l}71.5 \pm 3.0 \\
54.8 \pm 6.3 \\
42.5 \pm 7.2\end{array}$ \\
\hline
\end{tabular}

$\mathrm{R} \mathrm{u} \mathrm{u} \mathrm{k} \mathrm{k} \mathrm{i}$

Claying test on fen land. The peat on the test area consists of sedge peat. The area was worked over with the mattock and drained in the 1910's but was not brought into cultivation. It was ploughed in 1932 and the soil improvement test was established in 1933. Clay was added as soil improving agent at $0,100,200$ and $300 \mathrm{~m}^{3}$ per hectare. Various fertilizing tests were combined with the experiment. The plots with soil improving treatment, without fertilization and with annual nitrogen, phosphate and potassium fertilization $(100 \mathrm{~kg}$ calcium nitrate, $300 \mathrm{~kg}$ Kotka phosphate and $150 \mathrm{~kg} 40 \%$ potassium salt per hectare) were chosen as subjects of the present investigation. This experiment and its results have been described by AntTinen (2), and the location of the plots has been given in detail in his publication.

Claying and liming test on Sphagnum bog. The peat on the test area is Sphagnum peat. The area was worked over with the mattock and drained in the 1910's but it was not taken into actual cultivation until about ten years later. The thickness of the peat layer is only about $30-50 \mathrm{~cm}$. The properties of the peat on the test area are illustrated by the following compilation $(1$, p. 7$)$ : 


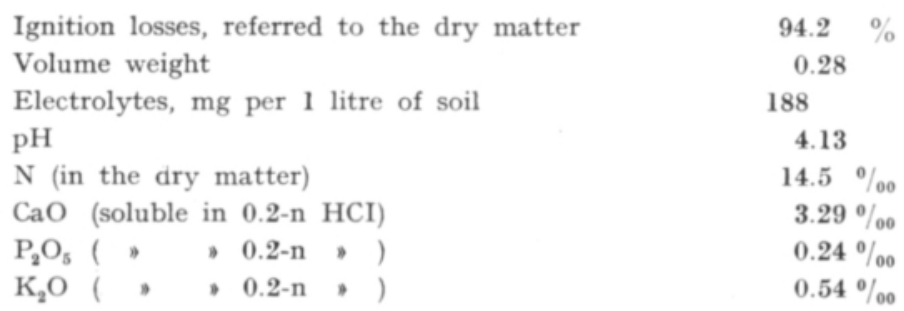

Different fertilizing tests were also combined with this experiment. The plots with soil improvement by 0 and $200 \mathrm{~m}^{3}$ clay per hectare (applied twice, in 1929 and $1935)$, by liming ( $3000 \mathrm{~kg}$ ground limestone per hectare in $1929,4000 \mathrm{~kg}$ per hectare in 1935 and $4000 \mathrm{~kg}$ per hectare in 1947) and by combined claying and liming were considered in the present investigation. In the last-mentioned treatment the claying and liming was done as in the treatments with one or the other treatment alone. Test samples were taken from the soil improvement test plots without fertilization and from plots that had been given nitrogen, phosphate and potassium fertilization (200 kg calcium nitrate, $400 \mathrm{~kg}$ Kotka phosphate and $200 \mathrm{~kg} 40 \%$ potassium salt per hectare). Antrinen ( 1 a) has described this test and its results and given an account of the location of the test plots.

\section{Methods of investigation}

The peat samples were taken in the following way. About $20-30$ samples extending to $10 \mathrm{~cm}$ depth from the soil surface were taken with the aid of a sampling cylinder $7.14 \mathrm{~cm}$ in diameter from each test plot, at equal distances along two parallel lines. The samples of the different replicates were not combined but were separately investigated. The samples were immediately spread out in a thin layer and air-dried. The moisture content of the peat was determined by keeping the peat samples 24 hours at $+110^{\circ} \mathrm{C}$. The ignition residue, in per cent. of the dry matter, was taken to represent the ash percentage of the peat.

\section{Results}

The results of the present investigation are compiled in Tables 3 and 4, where the figures after each value show the dispersion. It can be noted that the ash content of the peat in the plough layer has consistently increased as a consequence of cultivation through several decades. Addition of mineral soil as a soil improving agent on peat land has caused a remarkable increase in the ash content and it can be said that its effect on the properties of the soil seems to be very prolonged since the most recent addition in the present tests was made 25-27 years ago. It can be assumed that in the tests Nos. 4 and 6 transportation of soil from one soil improvement plot to another has occurred because the mineral soil was spread separately on each plot in these tests. The ash content established for the plot without treatment may be too high for this reason. 
Various substances are added to the soil as effects of cultivation, such as plant residues and root substance, which alter the original properties of the peat in the course of time. The increase of the ash content of the plough layer as a consequence of cultivation is thought to be one of the factors responsible for the phenomenon that cultivated peat land gradually loses its original character.

\section{Conclusions}

The results of this investigation justify the conclusion that the ash content of peat increases under cultivation through the effects of the administered fertilizers and soil improving agents. The ash content is increased in a particularly remarkable degree by addition of mineral soil as a soil improving agent. The ash content in the plough layer of cultivated peat lands which had received an addition of mineral soil as long as 37 years ago was found to be quite high. This would seem to indicate a prolonged effect of mineral soil on the properties of the plough layer. The increase of the ash content in the plough layer of cultivated peat land is obviously one of the factors responsible for the phenomenon that long-term cultivation of peat land slowly deprives the peat of its original character.

\section{REFERENCES}

(1) Antrinen, O. 1957. Rahkasuon lannoitus- ja maanparannuskokeen tuloksia. Referat: Ergebnisse eines Düngungs- und Bodenverbesserungsversuchs auf Sphagnum-Moor. Valt. maatal. koetoim. julk. 155: 1-29.

(2) - - 1957. Saraturvesuon saveus- ja lannoituskokeen tuloksia. Referat: Ergebnisse eines Lehmzufuhr- und Düngungsversuchs auf Seggentorfmoor. Ibid. 163: 1-20.

(3) Krvinen, E. 1948. Suotiede. Porvoo. 219 p.

(4) Pessi, Y. 1959. Kivennäismaan vaikutuksesta rahkasuon maanparannusaineena Leteensuon koeaseman pitkäaikaisten kenttäkokeiden perusteella. Summary: On the effect of mineral soil as a soil improving agent on Sphagnum bogs on the basis of prolonged field tests at Leteensuo Experimental Station. Acta agr. fenn. 94, 14: 241-268.

(5) - - 1960. Kivennäismaan merkityksestä mutasuon maanparannusaineena Leteensuon koeaseman pitkäaikaisten kenttäkokeiden perusteella. Summary: On the significance of mineral soil as a soil improving agent on fens on the basis of prolonged field tests at Leteensuo Experimental Station. Ibid. 95, 3.

(6) SrmolA, E. F. 1916. Uber die durch Kali- und Phosphorsäuredüngung auf einem Niedermoore bewirkten Schwankungen der Eigenschaften und Ernteerträge des Hafers. Helsinki. 32 p.

(7) VEsıкіvi, A. 1929. Suonsavetuksen ja -hiekoituksen taloudellisesta kannattavaisuudesta. Referat: Uber die Rentabilität der Lehm- und Sandmischkultur auf Moorboden. Suomen suovilj. yhd. tiet. julk. 12: 1-131. 
VILJELTYJEN TURVEMAIDEN MUOKKAUSKERROKSEN TUHKAPITOISUUDESTA

\author{
YRJö Pessi
}

\title{
Suoviljelysyhdistys, Leteensuon koeasema
}

Viljeltyjen turvemaiden muokkauskerroksen tuhkapitoisuutta on tutkittu Leteensuon, Tohmajärven ja Pohjois-Pohjanmaan koeaseman pitkäaikaisista maanparannus- ja lannoituskokeista. Tuloksista voidaan păätellä, että turpeen tuhkapitoisuus lisääntyy viljelyn yhteydessä käytettyjen lannoitteiden ja maanparannusaineiden vaikutuksesta. Erityisen huomattavasti tuhkapitoisuutta lisää kivennäismaan käyttö maanparannusaineena. Kun kivennäismaata oli lisätty 37 vuotta aikaisemmin, osoittautui muokkauskerroksen tuhkapitoisuus yhä edelleen suureksi. Tämä viittaisi kivennäismaan pitkäaikaiseen vaikutukseen suoviljelyksen maanparannusaineena. Viljeltyjen turvemaiden muokkauskerroksen tuhkapitoisuuden lisääntyminen on ilmeisesti eräs syy siihen, että kauan viljellyt suoviljelykset menettävät aikaa myöten alkuperäisen luonteensa ja muuttuvat vähitellen multamaita muistuttaviksi. 